\title{
PEMBERDAYAAN UKM BUMDES MARENAK SULUBOMBONG MELALUI DIVERSIFIKASI PRODUK SAMBAL ROA
}

\author{
Sri Sukari Agustina ${ }^{1}$, Ratmi Rosilawati ${ }^{2}$ dan Nurmawati Mambuhu ${ }^{3}$ \\ ${ }^{1}$ Staf Pengajar Fakultas Perikanan Universitas Muhammadiyah Luwuk \\ ${ }^{2}$ Staf Pengajar Fakultas Pertanian Universitas Muhammadiyah Luwuk \\ ${ }^{3}$ Staf Pengajar Fakultas Ekonomi dan Bisnis Universitas Muhammadiyah Luwuk \\ ${ }^{1}$ E-mail: sri.unismuhluwuk@gmail.com
}

\section{Article History:}

Received: 29-08-2021

Revised: 13-09-2021

Accepted: 23-09-2021

\section{Keywords:}

ikan, Marenak, pengasapan, roa, sambal, Sulubombong

\begin{abstract}
Desa Sulubombong berjarak sekitar $103 \mathrm{Km}$ dari Kota Luwuk ibu kota Kabupaten Banggai. Wilayah Desa Sulubombong berada di pesisir pantai. Mata pencaharian penduduk yang mendominasi yaitu nelayan dan petani. Pada umumnya kelompok nelayan Desa Sulubombong adalah nelayan penangkap ikan di laut, dimana pada musim-musim tertentu hasil tangkapan berupa ikan roa. Hasil tangkapan ikan roa yang melimpah di perairan laut sekitar Desa Sulubombong oleh masyarakat sekitar diolah secara tradisional dengan cara pengasapan. Tujuan kegiatan ini adalah untuk meningkatkan pengetahuan dan keterampilan pengurus UKM BUMDes Marenak Sulubombong mengenai diversifikasi produk sambal roa. Metode yang dipergunakan yaitu partisipatif, yang melibatkan secara langsung pengurus UKM BUMDes Marenak. Tahapan kegiatan meliputi kegiatan survey dan observasi ke lokasi mitra, persiapan bahan dan alat yang dipergunakan untuk kegiatan, sosialisasi ke masyarakat pengguna, dan pelatihan. Output luaran kegiatan yang dihasilkan yaitu adanya peningkatan pengetahuan dan keterampilan dalam mengolah produk serta peningkatan pendapatan pengurus dari diversifikasi produk sambal roa.
\end{abstract}

\section{Pendahuluan}

Desa Sulubombong terletak di Kecamatan Mantoh Kabupaten Banggai dan berjarak sekitar 103 Km dari Kota Luwuk ibu kota Kabupaten Banggai. Wilayah Desa Sulubombong berada di pesisir pantai dan memiliki luas wilayah $25.000 \mathrm{~m}^{2}$. Penduduk Desa Sulubombong terdiri dari $366 \mathrm{KK}$ berjumlah 1239 jiwa, dengan perincian 580 laki-laki dan 659 perempuan. Mata pencaharian pokok yang mendominasi penduduk Desa Sulubombong adalah nelayan dan petani, dimana ada 7 kelompok nelayan dan 3 kelompok tani (Sulubombong, 2017). Pada umumnya kelompok nelayan Desa Sulubombong adalah nelayan penangkap ikan di laut. Pada musim-musim tertentu hasil tangkapan dari laut berupa ikan roa. Ikan roa biasanya disebut dengan nama ikan julung-julung atau dengan nama latin Hemiramphus brasiliensis. Ikan roa adalah ikan pelagis yang hidup di perairan pantai ke arah lepas pantai dan hanya terlihat 
bergerombol di sekitar perairan karang ketika akan memijah karena ikan ini melepaskan telur di terumbu karang yang subur dan memiliki sumber makanan alami bagi induk maupun anakan ikan roa (Kawimbang et al., 2012).

Hasil tangkapan ikan roa yang melimpah di perairan laut sekitar Desa Sulubombong oleh masyarakat Desa Sulubombong diolah secara tradisional dengan cara pengasapan, yang dikenal dengan nama galafea. Hasil tangkapan ikan roa yang masih segar, dijual oleh nelayan harganya Rp. 25.000,- berisikan 20 ekor ikan roa dengan ukuran yang sudah siap untuk diasap. Ikan roa asap dari Desa Sulubombong dijual ke Luwuk, Gorontalo dan Manado dengan harga Rp. 60.000,- per kg. Rasa ikan roa asap ini sudah bukan menjadi rahasia lagi dan keistemewaannya sudah dapat dinikmati oleh masyarakat Indonesia bahkan mancanegara. Keistimewaan masakan ikan roa asap adalah sensasi perpaduan rasa ikan laut yang sudah diasapkan dengan rasa pedas.

Pada bulan September 2018 dalam rangka meningkatkan pendapatan masyarakat melalui sektor ketahanan pangan, Kepala Desa dan masyarakat Desa Sulubombong berinisiatif mendirikan UKM yang bisa mengolah dan memproduksi olahan ikan roa asap. Pada tanggal 1 Oktober 2018 atas kesadaran masyarakat, maka Kepala Desa Sulubombong mengukuhkan Susunan Pengurus Kelompok UKM BUMDes Marenak Sulubombong yang tertuang dalam Surat Keputusan No. 141.2/91/DS.SBONG/2018 yang beranggotakan 10 orang dengan Ketua UKM Ibu Sarti Taru (Sulubombong, 2018).

Sementara ini dengan teknologi yang sangat sederhana UKM BUMDes Maremak Sulubombong hanya mampu membuat satu jenis produk dari ikan roa asap berupa abon ikan roa yang dijual Rp. 75.000,- per 300 gram dalam kemasan plastik, sehingga usaha pembuatan abon ikan roa tidak bisa memberikan produksi dalam jumlah besar. Hal ini sangat menghambat perkembangan olahan produk, karena tingkat pendapatannya rendah dan tidak bisa berkembang kuantitas maupun kualitas produknya. Dalam potensi peningkatan sumberdaya manusianya khususnya pengurus UKM BUMDes "Marenak Sulubombong", maka perlu dilakukan kegiatan pemberdayaan UKM BUMDes Marenak Sulubombong melalui diversifikasi produk ikan roa asap. Program kegiatan ini dilaksanakan secara bersama dengan pengurus dalam suatu kelompok, sehingga diharapkan akan meningkatkan pengetahuan dan keterampilan dalam mengolah produk serta peningkatan pendapatan pengurus dari diversifikasi produk sambal roa. 


\section{Metode}

Pelaksanaan kegiatan "Pemberdayaan UKM BUMDes Marenak Sulubombong melalui diversifikasi produk sambal roa" dilaksanakan pada bulan Juli 2020 dan bulan Mei 2021 di Desa Sulubombong Kecamatan Mantoh Kabupaten Banggai. Metode pendekatan yang dilakukan menggunakan metode partisipastif sebagai suatu metode yang sangat dekat dengan metode pembelajaran pemberdayaan masyarakat.

Tahap kegiatan meliputi tahap persiapan kegiatan dan tahap pelaksanaan kegiatan. Pada tahap persiapan kegiatan yang dilaksanakan, diawali dengan survey lokasi ke Desa Sulubombong dan observasi terhadap mitra pengguna program. Kegiatan ini dilaksanakan pada tanggal 28 Juli 2020 dan bertujuan untuk memberikan pemahaman kepada masyarakat dan pengurus UKM BUMDes Marenak mengenai kegiatan yang dilakukan serta untuk mengetahui profil dan permasalahan yang dihadapi oleh mitra penggunan (UKM BUMDes Marenak Sulubombong) mengenai produk diversifikasi dari ikan roa asap. Pada tanggal 25 Mei 2021 dilanjutkan dengan persiapan alat, bahan dan materi kegiatan. Alat-alat yang diperlukan yaitu blender, pisau, loyang, kompor gas, wajan, pengaduk, dan timbangan analitik, sedangkan bahan yang diperlukan yaitu ikan roa asap, bumbu (untuk membuat sambal roa), tissue dan kertas stiker untuk label makanan. Wadah untuk produk sambal ikan roa berupa plastik kemasan, berbagai ukuran toples plastik.

Pada tahap pelaksanaan kegiatan dimulai dengan sosialisasi kepada mitra pengguna program (pengurus UKM BUMDes Marenak Sulubombong), dilanjutkan dengan pelaksanaan kegiatan pelatihan. Kegiatan ini dilaksanakan pada tanggal 26 Mei 2021 di lokasi UKM BUMDes Marenak Sulubombong. Tahapan kegiatan secara keseluruhan disajikan pada Tabel 1.

Tabel 1. Tahapan pelaksanaan kegiatan

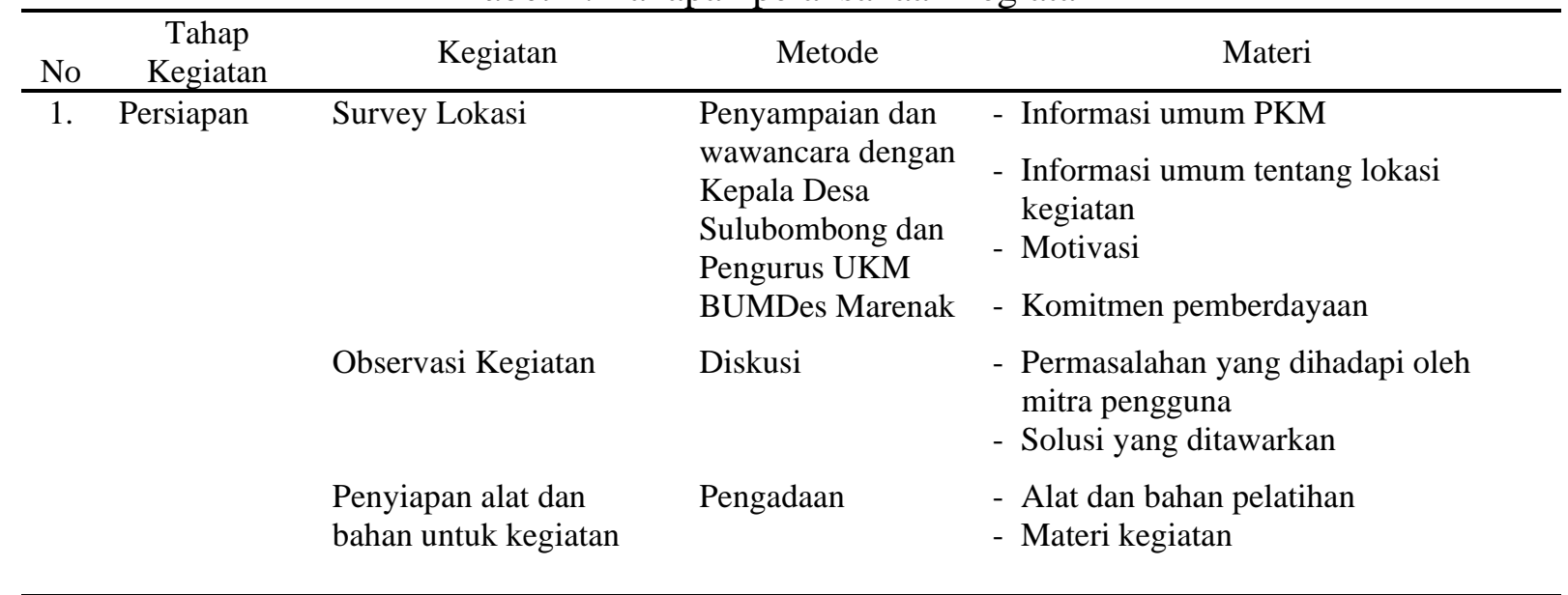




\begin{tabular}{|c|c|c|c|}
\hline 2. Pelaksanaan & $\begin{array}{l}\text { Sosialisasi ke } \\
\text { masyarakat sasaran }\end{array}$ & $\begin{array}{l}\text { Pertemuan dengan } \\
\text { mitra pengguna }\end{array}$ & $\begin{array}{l}\text { - Mekanisme pelaksanaan kegiatan } \\
\text { - Program-program yang dilaksanakan }\end{array}$ \\
\hline & $\begin{array}{l}\text { Pelaksanaan pelatihan } \\
\text { teknis }\end{array}$ & Partisipatif & $\begin{array}{l}\text { Pelatihan pembuatan diversifikasi } \\
\text { produk ikan roa (sambal ikan roa), } \\
\text { pelabelan dan pengemasan }\end{array}$ \\
\hline & $\begin{array}{l}\text { Pelaksanaan pelatihan } \\
\text { manajemen }\end{array}$ & Partisipatif & $\begin{array}{l}\text { Pelatihan manajemen dalam mengelola } \\
\text { kelompok dan pembukuan usaha }\end{array}$ \\
\hline
\end{tabular}

\section{Hasil}

Hasil kegiatan pemberdayaan UKM BUMDes Marenak Sulubombong melalui diversifikasi produk sambal roa di Desa Sulubombong Kecamatan Mantoh Kabupaten Banggai secara keseluruhan diuraikan sebagai berikut.

\section{Sosialisasi Ke Masyarakat Pengguna Program}

Sosialisasi ke masyarakat pengguna dalam hal ini pengurus UKM BUMDes Marenak Sulubombong dilaksanakan pada tanggal tanggal 26 Mei 2021. Metode yang dipergunakan dalam kegiatan sosialisasi yaitu partisipatif yang melibatkan secara langsung masyarakat pengguna dalam hal ini pengurus UKM BUMDes Marenak Sulubombong. Tujuan kegiatan sosialisasi ini adalah untuk melaksanakan kegiatan program pemberdayaan yang terjadwal dan tertuang dalam program kerja. Materi yang disampaikan antara lain : (a) Mekanisme pelaksanaan program kegiatan dan (b) Program-program yang dilaksanakan, meliputi :

1. Pelatihan pembuatan diversifikasi produk ikan roa, pengemasan dan pelabelan

2. Pelatihan manajemen dalam mengelola kelompok dan pembukuan usaha

Dokumentasi kegiatan sosialisasi dengan mitra pengguna tertuang pada Gambar 1 berikut.
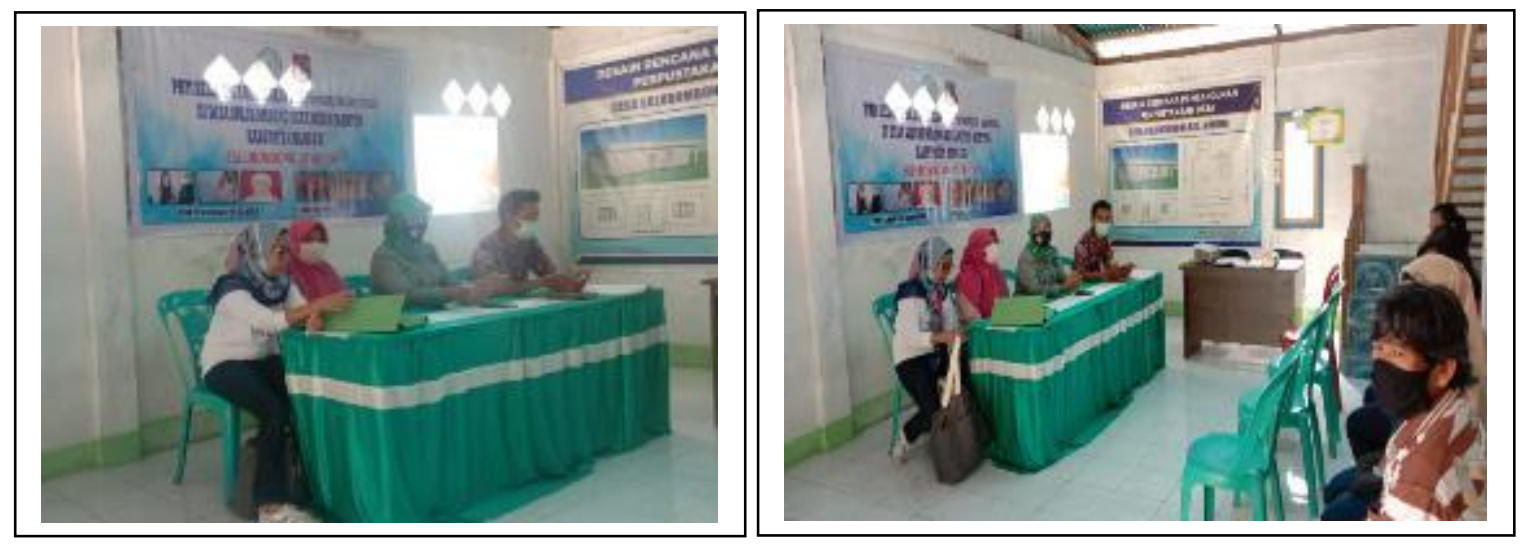

Gambar 1. Kegiatan pemaparan sosialisasi program dengan mitra pengguna

\section{Pelatihan Diversifikasi Produk Sambal Roa, Pengemasan dan Pelabelan}

Pelatihan diversifikasi produk ikan sambal, pengemasan dan pelabelan pada pengurus UKM BUMDes Marenak Sulubombong dilaksanakan pada tanggal 26 Mei 2021 di kantor 
UKM BUMDes Marenak Sulubombong. Diversifikasi produk ikan roa asap yang dikembangkan pada kegiatan pelatihan ini adalah sambal roa Sulubombong. Tujuan daripada kegiatan ini adalah meningkatkan pengetahuan dan keterampilan pengurus UKM BUMDes Marenak mengenai tata cara pembuatan sambal roa, pengemasan dan pelabelan dari kemasan sambal roa. Alur kegiatan pelatihan tertuang pada Gambar 2.

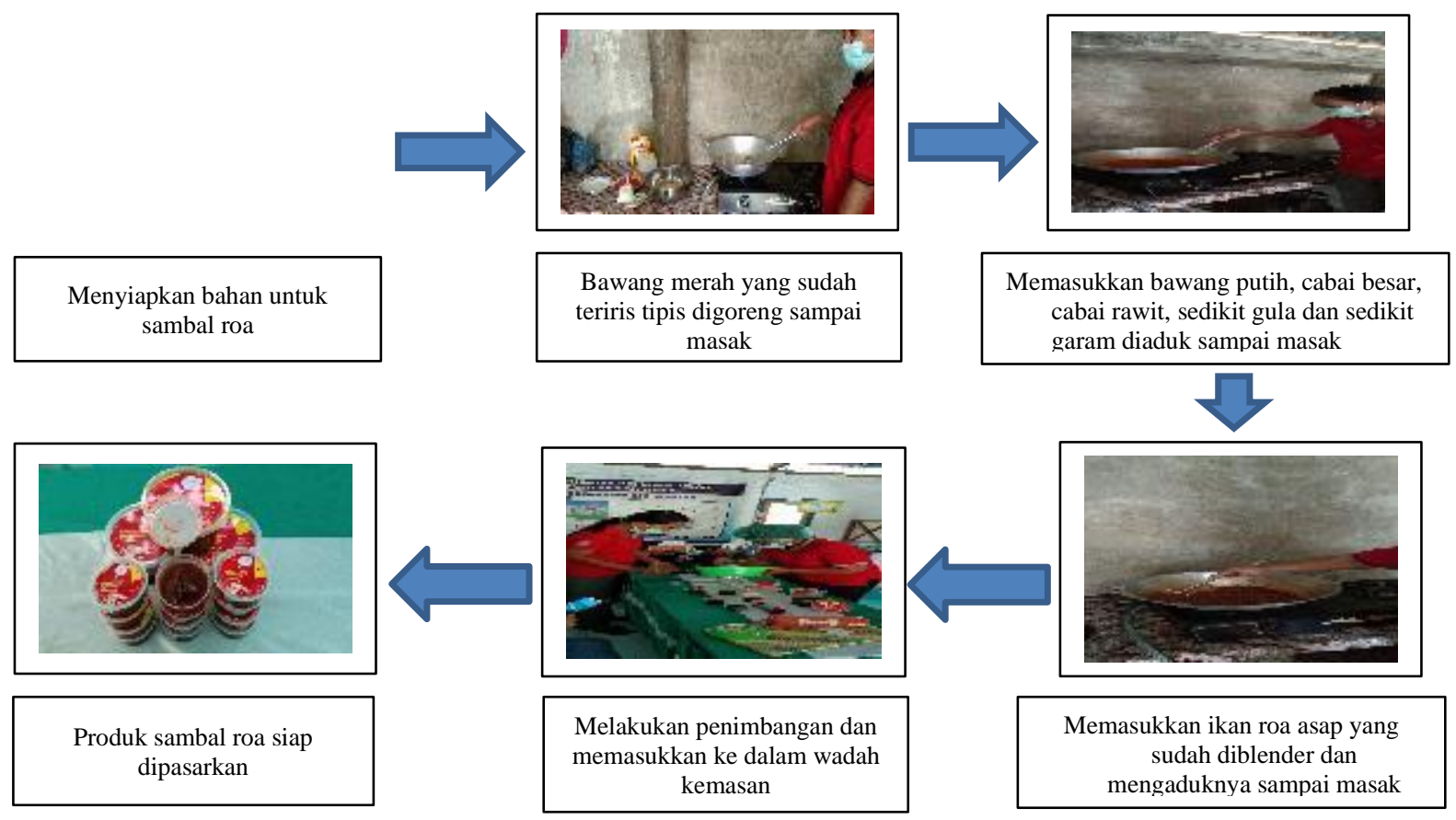

Gambar 2. Alur kegiatan pelatihan pembuatan sambal roa, pengemasan dan pelabelan

\section{Pelatihan Manajemen Dalam Mengelola Kelompok dan Pembukuan Usaha}

Pelatihan manajemen dalam mengelola kelompok dan pembukuan usaha pada pengurus UKM BUMDes Marenak Sulubombong dilaksanakan pada tanggal 26 Mei 2021 di kantor UKM BUMDes Marenak Sulubombong. Tujuan daripada kegiatan ini adalah meningkatkan pengetahuan dan keterampilan pengurus UKM BUMDes Marenak mengenai manajemen dalam mengelola kelompok dan pembukuan usaha. Materi yang diberikan yaitu mengenai manajemen dalam mengelola kelompok dan pembukuan usaha sederhana untuk pengurus UKM BUMDes Marenak. Dokumentasi kegiatan pelatihan tersebut tertuang pada Gambar 3. 

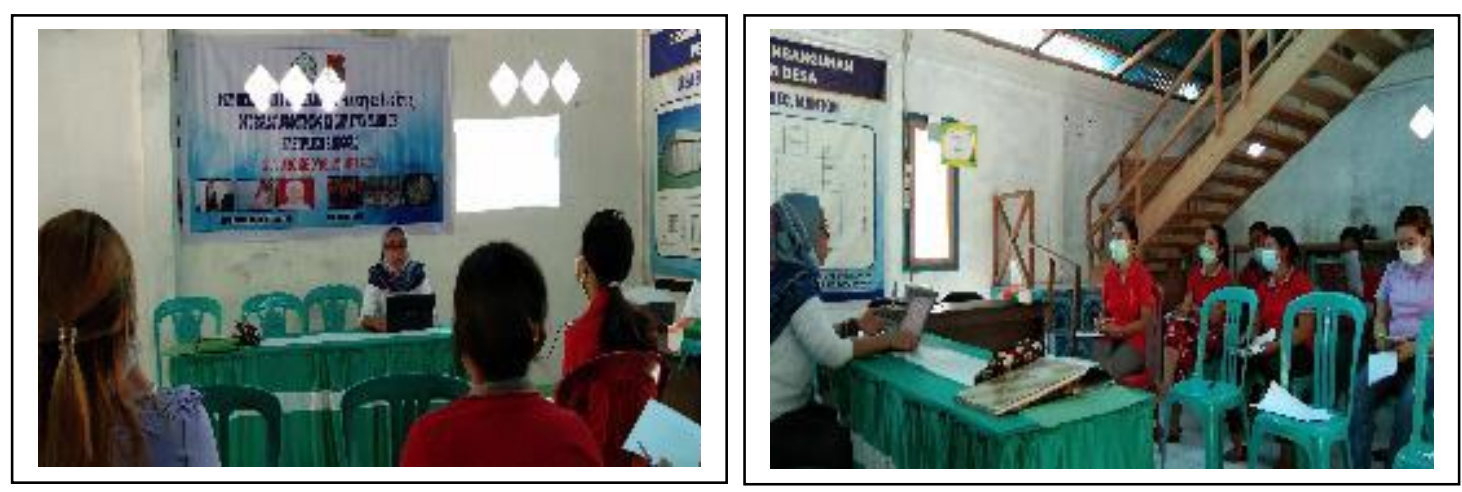

Gambar 3. Pelatihan manajemen dalam mengelola kelompok dan pembukuan usaha

\section{Pembahasan}

Ikan roa termasuk salah satu jenis ikan yang diolah dengan cara pengasapan. Ciri-ciri umum ikan roa adalah sebagai berikut badan memanjang, langsing seperti cerutu, rahang memanjang dan berduri keras, kuat seperti gigi, rahang bawah panjang melebihi rahang atas dengan sirip ekor bercabang dan bagian bawah lebih panjang, Warna punggung biru kehijauan, bagian perut berwarna putih keperakan, terdapat garis berwarna biru tua pada bagian sisi tubuh, panjang total pada umumnya $30 \mathrm{~cm}$ (Nelson, 1984 dalam (Dotulong et al., 2018). Seperti produk ikan asap lainnya, ikan roa mempunyai mutu yang baik agar tetap digemari oleh konsumen. Mutu adalah nilai-nilai tertentu yang diinginkan pada suatu produk. Saanin (1984) dalam (Dotulong et al., 2018), komposisi ikan julung-julung segar adalah air $79,98 \%$, protein $18,02 \%$, lemak $1,45 \%$ dan abu $0,01 \%$.

Ikan roa merupakan salah satu jenis ikan ekonomis penting karena memiliki rasa yang gurih dan sangat diminati oleh pasar apalagi untuk produk ikan roa asap, sehingga harganya juga tetap stabil. Ikan roa asap ini sering diolah menjadi sambal roa. Sambal roa Sulubombong merupakan hasil dari diversifikasi ikan roa asap yang dibuat oleh UKM BUMDes Marenak Sulubombong Kecamatan Mantoh Kabupaten Banggai melalui kegiatan pemberdayaan. Kartasasmita (1996) dalam (Helmi Alhadar, Bakri La Suhu, Marno Wance, Vivi Noviyanti, 2020) pemberdayaan masyarakat bisa dilakukan oleh banyak elemen yaitu pemerintah, perguruan tinggi, lembaga swadaya masyarakat, pers, partai politik, lembaga donor, aktor-aktor masyarakat sipil, atau oleh organisasi masyarakat lokal sendiri.

Kegiatan pemberdayaan UKM BUMDes Marenak Sulubombong bertujuan (1) untuk meningkatkan pengetahuan dan keterampilan pengurus UKM BUMDes Marenak mengenai diversifikasi ikan roa asap yang bisa dijadikan sambal roa dengan kemasan yang menarik konsumen, sehingga mendapatkan nilai jual yang tinggi, dan (2) meningkatkan pengetahuan 
dan keterampilan pengurus UKM BUMDes Marenak Sulubombong mengenai manajemen mengelola kelompok dan pembukuan usaha. Sehingga dengan adanya dua tujuan tersebut, pengurus UKM BUMDes Marenak Sulubombong bisa meningkatkan pendapatan, kuantitas dan kualitas melalui diversikasi produk ikan roa asap.

\section{Kesimpulan}

Berdasarkan hasil kegiatan pemberdayaan UKM BUMDes Marenak Sulubombong melalui diversifikasi produk sambal roa dapat ditarik kesimpulan bahwa terdapat peningkatan pengetahuan, keterampilan dan penguasaan teknologi tepat guna pengurus UKM BUMDes Marenak Sulubombong mengenai pembuatan produk sambal roa, cara pengemasan dan pelabelan dan Hasil kegiatan pemberdayaan ini diperoleh output kegiatan yaitu: (a) menghasilkan desain kemasan sehingga menarik konsumen, (b) terwujudnya kelompok yang baik dalam manajemen dan mengelola keuangan, (c) menumbuhkan jiwa enterpreneurship dan professional kepada pengurus kelompok mitra dalam mengembangkan produk ikan roa asap menjadi produk industri rumah tangga yang kreatif dan inovatif.

\section{Daftar Referensi}

Dotulong, V., Patty, C. N., \& Suwetja, I. K. (2018). MUTU IKAN ROA (Hemirhamphus sp) ASAP YANG DIJUAL DI PASAR BERSEHATI KOTA MANADO SULAWESI UTARA. MEDIA TEKNOLOGI HASIL PERIKANAN, 6(3), 88. https://doi.org/10.35800/mthp.6.3.2018.21386

Helmi Alhadar, Bakri La Suhu, Marno Wance, Vivi Noviyanti, K. A. (2020). PEMBERDAYAAN KELOMPOK USAHA KECIL MASYARAKAT DESA MADOPOLO MELALUI PROGRAM NASIONAL PEMBERDAYAAN MASYARAKAT (PNPM) MANDIRI. JURNAL GOVERNMENT OF ARCHIPELAGO (JGOA), 1(2).

Kawimbang, E., Paransa, I. J., \& Kayadoe, M. E. (2012). Pendugaan stok dan musim penangkapan ikan julung-julung dengan soma roa di perairan Tagulandang, Kabupaten Kepulauan Siau Tagulandang Biaro. JURNAL ILMU DAN TEKNOLOGI PERIKANAN TANGKAP, 1(1). https://doi.org/10.35800/jitpt.1.1.2012.701

Sulubombong, P. D. (2017). RPJM Desa Sulubombong. Rencana Pembangunan Jangka Menengah (RPJM Desa) Tahun 2017-2022 Desa Sulubombong Kecamatan Mantoh Kabupaten Banggai.

Sulubombong, P. D. (2018). Surat Keputusan Kepala Desa Sulubombong No. 141.2/91/DS.SBONG/2018 Tentang Pengukuhan Kelompok UKM BUMDES MARENAK SULUBOMBONG. 